\title{
39. PALEOMAGNETIC RESULTS FROM EARLY TERTIARY/LATE CRETACEOUS SEDIMENTS OF SITE 384
}

\author{
P. A. Larson and N. D. Opdyke, Lamont-Doherty Geological Observatory, Palisades, New York
}

\begin{abstract}
Magnetic measurements were made on samples taken from the region of the Tertiary/Cretaceous boundary at Site 384 . We had hoped that the magnetic stratigraphy of this section could be used to independently substantiate the magnetic stratigraphy of a section of the same age at Gubbio, Italy. Although an attempt has been made to correlate the two sections, the quality of the magnetic data is too poor either to confirm or deny the Gubbio results.
\end{abstract}

\section{INTRODUCTION}

A type section for the Late Cretaceous-Paleocene portion of the geomagnetic reversal time scale has been proposed recently from studies of the pelagic limestone sequence at Gubbio, Italy (Alvarez et al., 1977; Lowrie and Alvarez, 1977; Roggenthen and Napoleone, 1977). The upper Maestrichtian-Danian sediments from Site 384 were studied to see whether they would yield a magnetic stratigraphy correlative to the section at Gubbio.

\section{DISCUSSION}

Vertically oriented cylindrical samples of 10 -cc volume were taken approximately every 10 to $20 \mathrm{~cm}$ between 155 and 179 meters sub-bottom (Cores 12, 13, and 14). Four pilot specimens were progressively demagnetized in 50-oe steps up to a peak alternating field of 300 oe (Figure 1). Three samples (13-2, 116 $\mathrm{cm} ; 13-2,126 \mathrm{~cm} ; 13-3,112 \mathrm{~cm}$ ) contained significant secondary components of magnetization which were not entirely removed by AF demagnetization.

For all specimens, we measured the direction and intensity of natural remanent magnetization (NRM) and of the remanence remaining after cleaning in an alternating field of 150 oe. A plot of the inclinations after 150-oe cleaning appears in Figure 2. The samples between 167.2 and 174.5 meters were measured on a slow-speed, high-sensitivity Digico magnetometer (Molyneux, 1971). This instrument was unavailable for use on the other specimens, so most of the remaining measurements were made on a $105-\mathrm{Hz}$ PAR spinner magnetometer. During the course of these measurements, static charge became a problem; the few remaining specimens were measured on a slow-speed spinner magnetometer (Foster, 1966). In Figure 2, the circles denote inclinations measured by the Digico, the squares are values from the PAR, and the triangles are values from the Foster magnetometer. Using Late Cretaceous and early Tertiary poles for North America of $71.0^{\circ} \mathrm{N}, 179.0^{\circ} \mathrm{E}$ and $75.6^{\circ} \mathrm{N}, 184.5^{\circ} \mathrm{E}$, respectively (Van der Voo and French, 1974), the expected dipole inclination for this section of Site 384 should lie between $46^{\circ}$ and $58^{\circ}$. This range of inclinations is indicated by the two stippled bands on the plot in Figure 2. As can seen in the figure, the actual inclination values are considerably scattered. The normally magnetized specimens have an average inclination of $43.3^{\circ}$ ( standard deviation $=19.6^{\circ}$ ), while the reversely magnetized ones average $-24.9^{\circ}$ (standard deviation $=22 \cdot 1^{\circ}$ ). These averages exclude specimens which fall within the two hachured zones in the polarity diagram of Figure 2. Intensities of magnetization after a.f. demagnetization vary from $1.3 \times 10^{-7}$ to $6.4 \times 10^{-6} \mathrm{emu} /$ $\mathrm{cm}^{2}$ with an average value of $1.7 \times 10^{-6} \mathrm{emu} / \mathrm{cm}^{2}$ (standard deviation $=1.3 \times 10^{-6} \mathrm{emu} / \mathrm{cm}^{2}$ ).

Figure 2 also provides an interpretation of the magnetic polarity. The wide scatter in the inclinations, which is probably due to the instability of magnetization, makes this interpretation difficult, particularly between 166 and 171.5 meters (in the region of the Tertiary/Cretaceous boundary) and below 176 meters. The black and white blocks in the figure indicate zones of normal and reversed polarity, respectively. The hachured blocks are intervals which are probably normally magnetized. Within Core 12 , we interpret a reversely magnetized zone from 155.96 to 156.72 meters, which is followed by normally magnetized material between 156.72 and 161.25 meters and another reversed zone from 161.25 to 162.58 meters. The normal zone which begins near the bottom of Core 12 at 162.58 meters continues into Core 13 and ends at $\sim 168.10$ meters. The shipboard paleontologists placed the Tertiary/Cretaceous boundary at 167.92 meters, at the very base of this normally magnetized zone. Continuing down the core, reversed material lies between $\sim 168.10$ and $\sim 169.05$ meters. The normally magnetized interval beneath this extends to at least 170.28 meters and perhaps as far as $\sim 171.10$ meters. The sediment from $\sim 171.10$ to 171.68 meters is of reversed polarity. From 171.68 to 175.85 meters, below which the data in Core 14 are too scattered to interpret, the polarity is normal.

A comparison of the magnetic stratigraphy with that which was observed at Gubbio, Italy, by Alvarez et al. 

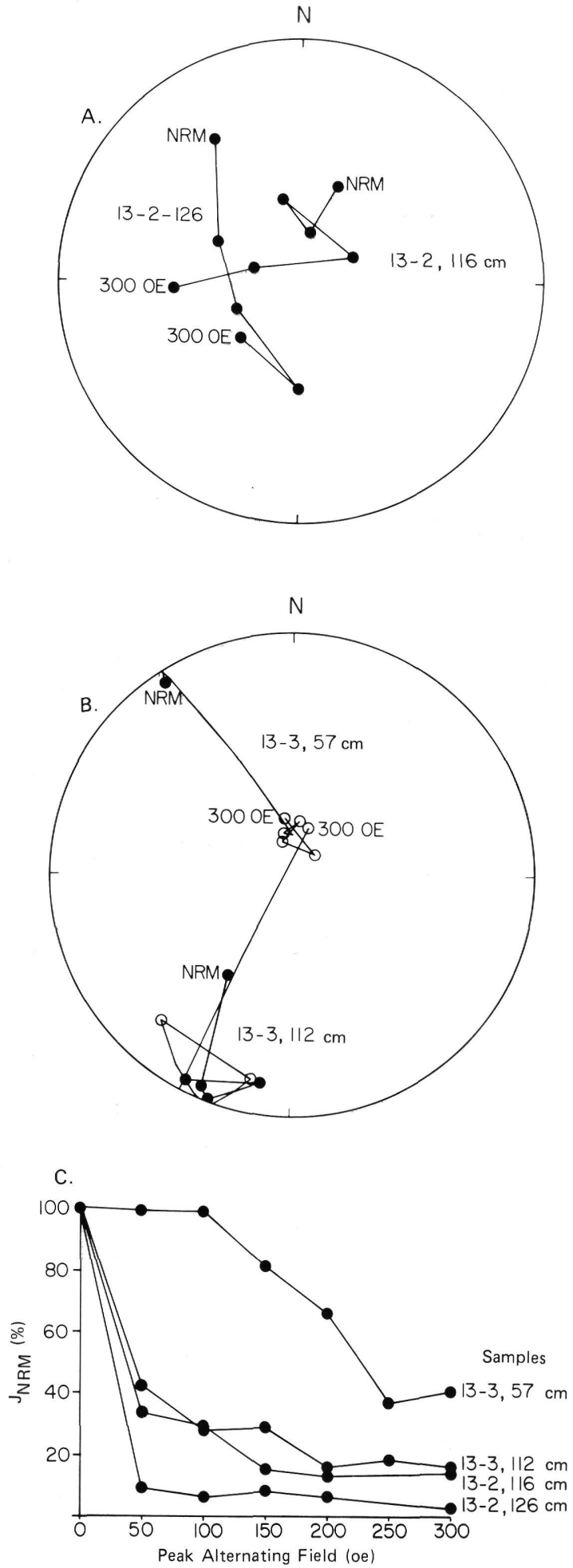

Figure 1. Site 384 a.f. demagnetization of two normally $(13-2,116 \mathrm{~cm} ; 13-2,126 \mathrm{~cm})$ and two reversely $(13-3$, $57 \mathrm{~cm} ; 13-3,112 \mathrm{~cm}$ ) magnetized samples. (A and $B$ ) Change in direction of magnetization during progressive a.f. demagnetization plotted on stereographic projections. Filled circles are positive inclinations; open circles are negative inclinations. (C) Plot of the change of magnetization intensity with respect to peak alternating field.
SITE 384

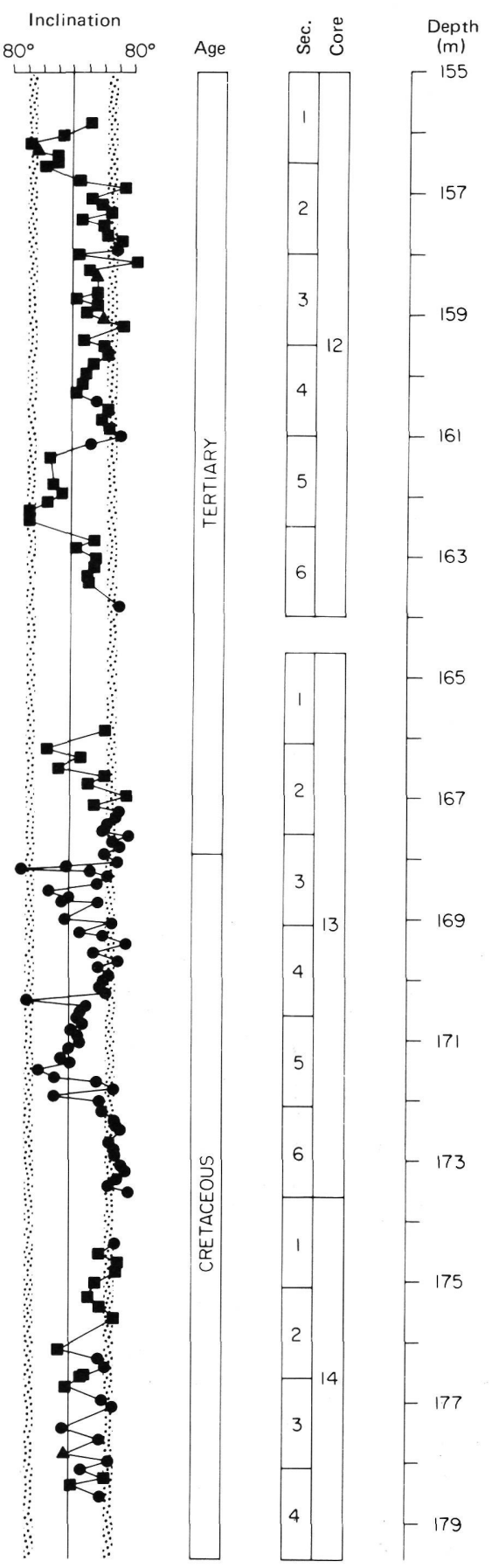

Figure 2. Inclination data versus sub-bottom depth. Values are those measured after AF demagnetization in a 150-oe peak alternating field. Three different magnetometers were used in measuring the samples (see text); solid circles $=$ Digico, solid squares $=P A R$, solid triangles $=$ Foster. The stippled bands contain the range of dipole inclinations calculated from Late Cretaceous and early Tertiary pole positions for North America taken from Van der Voo and French (1974). In the magnetic polarity zonation on the left, the reversed zones are white, normal zones are black or hachured (see text). 
(1977) and with the Tertiary/Cretaceous part of the sea-floor spreading geomagnetic time scale (LaBrecque et al., 1977) is shown in Figure 3. Micropaleontologic biohorizons for this part of Site 384 help establish the correlations more firmly. The first appearance of foraminifer G. trinidadensis (Kaneps, this volume) occurs near the top of the normal interval, which is between 156.72 and 161.25 meters. In the Gubbio section, this datum occurs in Zone J + (anomaly 28 ); hence, this interval is correlated to anomaly 28 . That the next lower normal interval $(162.58$ to $\sim 168.10 \mathrm{~m})$ corresponds to anomaly 29 is supported by the presence of the first occurrence of nannolith $C$. danicus (Thierstein and Okada, this volume). This is because the oldest nannofossils recovered at DSDP Site 245, which was drilled on the older side of anomaly 29 (Schlich, 1974) in the western Indian Ocean, belonged to the $C$. danicus Zone (Bukry, 1974; Simpson, Schlich, et al., 1974). The normal zone below 171.68 meters contains the bases of both $M$. mura (Thierstein and Okada, this volume) and A. mayaroensis (McNulty, this volume) zones. Both of these horizons dictate an anomaly 31 age for this interval because the nannolith $M$. mura was recovered from the bottom of DSDP Site 239 (Bukry, 1974), which was drilled on reversely magnetized crust just older than anomaly 31 (Schlich, 1974) in the Madagascar Basin. In the Gubbio section, Alvarez et al. (1977) find the first appearance of the foraminifer $A$. mayaroensis in Zone $\mathrm{F}_{1}{ }^{+}$(anomaly 31 ). It should be noted that based on the DSDP Site 239 and Gubbio sections, the relative positions of these two biohorizons are reversed at Site 384 . The remaining zone of normal polarity $(\sim 169.05$ to $\sim 171.10 \mathrm{~m})$ is then correlative to anomaly 30 .

\section{CONCLUSION}

The location of the Tertiary/Cretaceous boundary at the base of the normal zone which is correlated to anomaly 29 is only apparently at odds with its occurrence in the reversely magnetized zone between anomalies 29 and 30 in the Gubbio, Italy, section. The coincidence of this boundary with a magnetic reversal, coupled with the abrupt changes in lithology and paleontology noted by the shipboard scientists in the Site 384 sequence, suggests the biostratigraphic boundary may lie within a hiatus.

\section{ACKNOWLEDGMENTS}

The authors thank D. V. Kent and R. L. Larson for reviewing this report, and $M$. Turner and D. Lafferty for making the measurements. This work was supported by research Grant OCE 76-21962 of the National Science Foundation to Columbia University.

\section{REFERENCES}

Alvarez, W., Arthur, M. A., Fischer, A. G., Lowrie, W., Napoleone, G., Premoli Silva, I., and Roggenthen, W. M., 1977. Upper Cretaceous-Paleocene magnetic stratigraphy at Gubbio, Italy, V. Type section for the late CretaceousPaleocene geomagnetic reversal time scale; Geol. Soc. Am. Bull, v. 88, p. 382-389.

Bukry, D., 1974, Phytoplankton stratigraphy, offshore East Africa, Deep Sea Drilling Project Leg 25. In Simpson, E. S. W., Schlich, R., et al., Initial Reports of the Deep Sea Drilling Project, v. 25: Washington (U.S. Government Printing Office), p. 635-646.

Foster, J. H., 1966. A paleomagnetic spinner magnetometer using a fluxgate gradiometer; Earth Planet. Sci. Lett., v. 1, p. 463-466.

LaBrecque, J. L., Kent, D. V., and Cande, S. C., 1977. Revised magnetic polarity time scale for Late Cretaceous and Cenozoic time; Geology, v. 5, p. 330-335.

Lowrie, W. and Alvarez, W., 1977. Upper Cretaceous-Paleocene magnetic stratigraphy at Gubbio, Italy, III. Upper Cretaceous magnetic stratigraphy; Geol. Soc. Am. Bull., v. 88 , p. $374-377$.

Molyneux, L., 1971. A complete result magnetometer for measuring the remanent magnetization of rocks; Geophys. J. Roy. Astron. Soc, v. 24, p. 1-5.

Roggenthen, W. M and Napoleone, G., 1977. Upper Cretaceous-Paleocene magnetic stratigraphy at Gubbio, Italy, IV. Upper Maastrichtian-Paleocene magnetic stratigraphy; Geol. Soc. Am. Bull., v. 88, p. 378-382.

Schlich, R., 1974. Sea floor spreading history and deep-sea drilling results in the Madagascar and Mascarene basins, western Indian Ocean. In Simpson, E. S. W., Schlich, R., et al., Initial Reports of the Deep Sea Drilling Project, v. 25: Washington (U.S. Government Printing Office), p. 663-678.

Simpson, E. S. W., and Schlich, R., et al., 1974, Site 245. In Simpson, E. S. W., Schlich, R., et al., Initial Reports of the Deep Sea Drilling Project v. 25: Washington (U.S. Government Printing Office), p. 187-208.

Van der Voo, R., and French, R. B., 1974. Apparent polar wandering for the Atlantic-bordering continents: Late Carboniferous to Eocene; Earth-Sci. Rev., v. 10, p. 99119. 


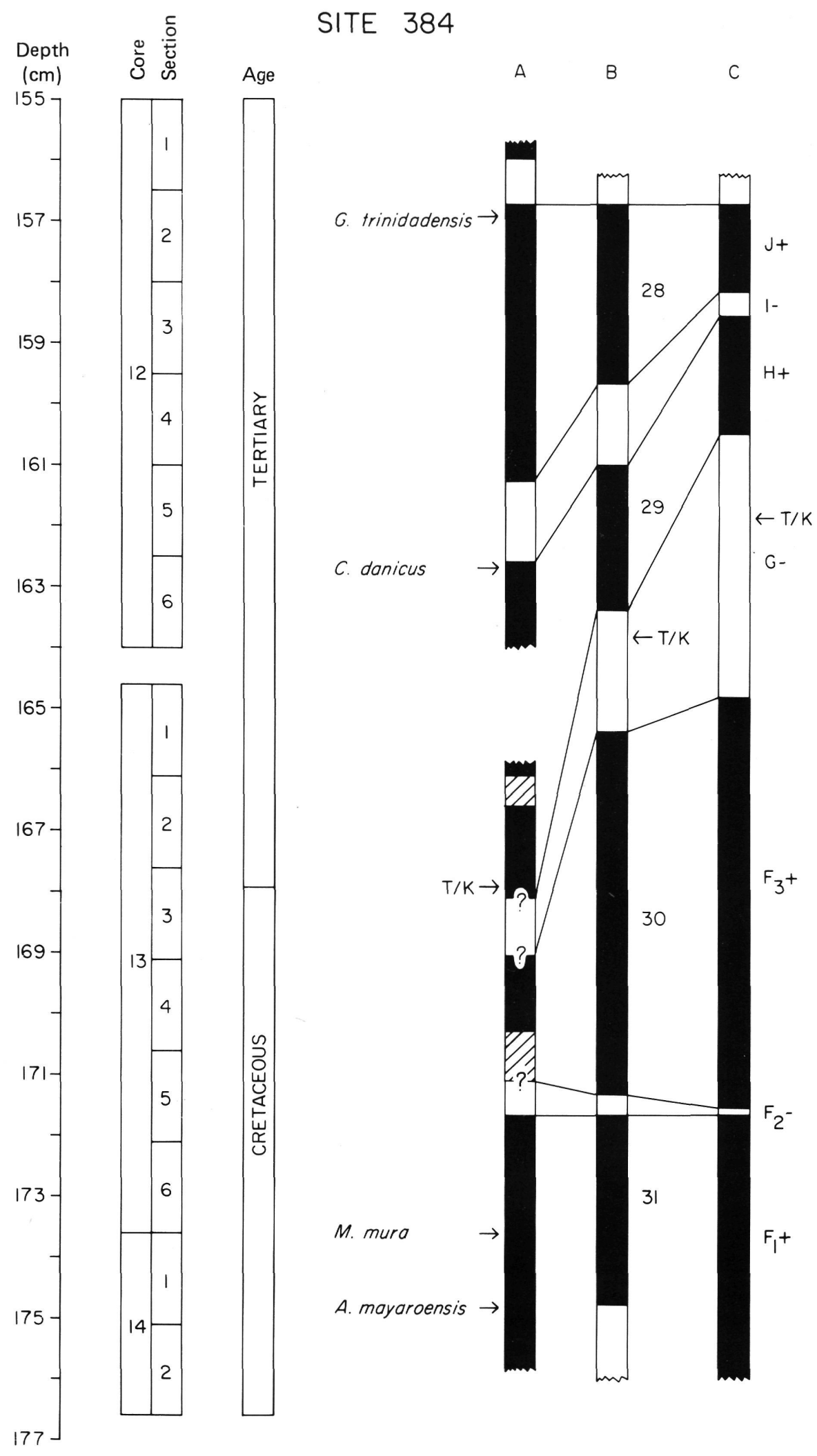

Figure 3. Comparison of magnetic polarity zonation of Site 384 (column A) with the marine geomagnetic time scale (column B; after LaBrecque, et al., 1977) and the magnetic stratigraphy at Gubbio, Italy (column C; after Alvarez et al., 1977). Black, hachured, and white zones are as in Figure 2. The micropaleontologic biohorizons mark the first appearances of the indicated taxa. The Tertiary/Cretaceous boundary is indicated by $T / K$. 